\begin{tabular}{|c|c|}
\hline Citation & $\begin{array}{l}\text { Authors } \\
\text { Veryser Cedrick, Steurs Gert, Van Meervelt Luc, De Borggraeve Wim }\end{array}$ \\
\hline & $\begin{array}{l}2018 \\
\text { Intramolecular Carbonylative C-H Functionalization of 1,2,3- Triazoles for } t \\
\text { he Synthesis of Triazolo[1,5-a]indolones }\end{array}$ \\
\hline & Journal \\
\hline & Advanced Synthesis and Catalysis \\
\hline & Pages:1271-1276 \\
\hline Archived version & Manuscript before formatting by journal \\
\hline Published version & http://dx.doi.org/10.1002/adsc.201601388 \\
\hline Journal homepage & http://onlinelibrary.wiley.com/journal/10.1002/(ISSN)1615-4169 \\
\hline Author contact & $\begin{array}{l}\text { wim.deborggraeve@kuleuven.be } \\
+32(0) 16327693\end{array}$ \\
\hline LIRIAS & https://lirias.kuleuven.be/handle/123456789/574847 \\
\hline
\end{tabular}

(article begins on next page) 


\title{
Intramolecular Carbonylative C-H Functionalization of 1,2,3- Triazoles for the Synthesis of Triazolo[1,5-a]indolones
}

\author{
Cedrick Veryser, ${ }^{\mathrm{a}}$ Gert Steurs, ${ }^{\mathrm{a}}$ Luc Van Meervelt, ${ }^{\mathrm{b}}$ and Wim M. De Borggraeve ${ }^{\mathrm{a}, *}$ \\ a Molecular Design and Synthesis, Department of Chemistry, KU Leuven, Celestijnenlaan 200F, box 2404, 3001 Leuven, \\ Belgium. \\ Phone: (+32) 16327693 and wim.deborggraeve@kuleuven.be \\ b Biochemistry, Molecular and Structural Biology, Department of Chemistry, KU Leuven, Celestijnenlaan 200F, box \\ 2404, 3001 Leuven, Belgium.
}

Received: ((will be filled in by the editorial staff))

Supporting information for this article is available on the WWW under http://dx.doi.org/10.1002/adsc.201\#\#\#\#\#.((Please delete if not appropriate))

\begin{abstract}
This study presents a synthesis of $4 H$ - $[1,2,3]$ triazolo[1,5- $a]$ indol-4-ones. The key step in the synthesis of this new heterocyclic scaffold is an intramolecular cyclization via an unprecedented carbonylative $\mathrm{C}$-H functionalization of 1-(2-bromoaryl)1,2,3-triazoles. Isotopic labeling of the carbonyl carbon atom is possible using near stoichiometric amounts of ${ }^{13} \mathrm{CO}$. Additionally, an alternative pathway via carbonylative Sonogashira coupling followed by a two-step one pot azidation/cycloaddition is also investigated, giving rise to the same scaffold.
\end{abstract}

Keywords: 1,2,3-triazoles; carbonylation; C-H activation; heterocycles; isotopic labeling

Over the past decade, transition metal-catalyzed C-H functionalization has emerged as a valuable strategy in organic synthesis. ${ }^{[1]}$ This strategy is challenging, as it has to deal with the inertness of a $\mathrm{C}-\mathrm{H}$ bond, but is also beneficial in terms of atom economy, since typical prefunctionalization steps (such as halogenation and borylation) can be circumvented by directly addressing a $\mathrm{C}-\mathrm{H}$ bond. One relevant example for this study is the discovery of the direct arylation of 1,2,3-triazoles (Scheme 1a). ${ }^{[2]}$

While transition metal-catalyzed direct arylation is widely explored, the carbonylative equivalent still poses great scientific challenges to date. ${ }^{[3]}$ This problem has partially been addressed by using activated substrates

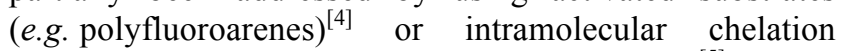
(e.g. nitrogen coordination, directing group). ${ }^{[5]}$ Other methods involve in situ formation of an organocuprate ${ }^{[6]}$ or in situ halogenation. ${ }^{[7]}$ One example is the pioneering work of the Larock group in 2000, discussing the intramolecular carbonylative $\mathrm{C}-\mathrm{H}$ functionalization of $o$-halobiaryls for the synthesis of fluorenone derivates (Scheme 1b) ${ }^{[8]}$ Recently, the scope of this transformation was expanded, as it turned out that (fused) 5-membered heterocycles were also suitable substrates. ${ }^{[9]}$ Progress has also been made on the more challenging intermolecular transformation as the Arndtsen group developed a general procedure to perform carbonylative $\mathrm{C}$-H functionalization on 5-membered nitrogen-containing heterocycles. ${ }^{[10]}$

To our surprise, neither intra- nor intermolecular carbonylative $\mathrm{C}-\mathrm{H}$ functionalization of 1,2,3-triazoles has been reported to date. This type of transformation could however be a valuable new strategy towards highly substituted triazoles which are omnipresent since the discovery of the click reaction. In this report, we present our results of the first intramolecular carbonylative $\mathrm{C}-\mathrm{H}$ functionalization of triazoles. This pathway gives direct access to a new heterocyclic scaffold: the triazolo[1,5a] indolone (Scheme 1c).

Previous work:

(a) C-H arylation of 1,2,3-triazoles

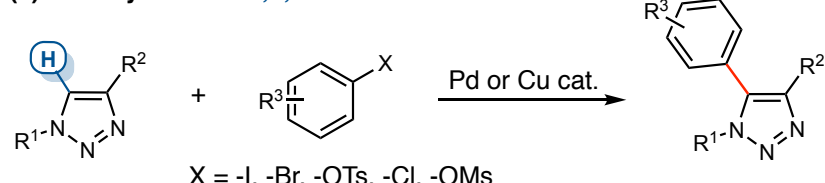

(b) Carbonylative $\mathrm{C}-\mathrm{H}$ functionalization of $o$-halobiaryls
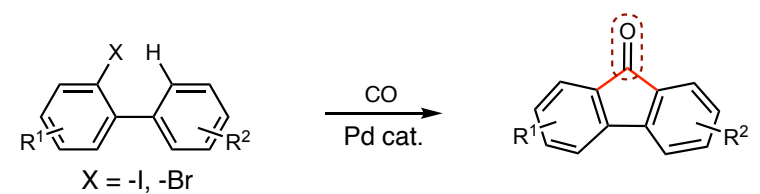

This work:

(c) Carbonylative C-H functionalization of 1,2,3-triazoles
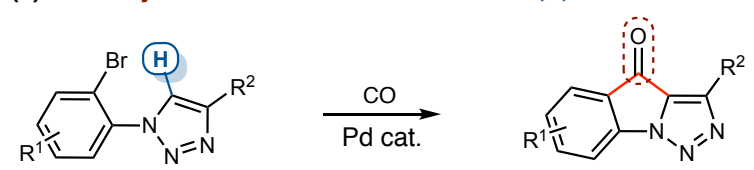

Scheme 1. Transition metal-catalyzed (carbonylative) C-H functionalization. 
$\underbrace{}_{N=N}$

4

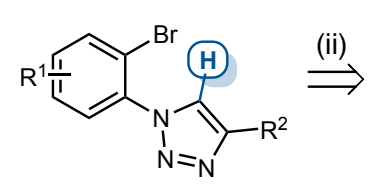

3

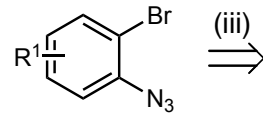<smiles></smiles>

$\mathrm{R}^{1}=-\mathrm{H},-\mathrm{Me},-\mathrm{OMe},-\mathrm{COOMe},-\mathrm{F}$ $\mathrm{R}^{2}=$-alkyl, -aryl, -Si(alkyl) 3

1

Scheme 2. Retrosynthetic strategy for the synthesis of triazolo[1,5-a]indolones: (i) carbonylative C-H functionalization, (ii) cycloaddition and (iii) functional group interconversion.

The triazolo[1,5- $a]$ indolones were synthesized via a sequential procedure, using 2-bromoanilines as readily available starting materials (Scheme 2). First, 2-bromoanilines 1 were converted into their corresponding azides $\mathbf{2}$ in the presence of tert-butyl nitrite and azidotrimethylsilane (see ESI). ${ }^{[1]}$

The second step, the cycloaddition of 2-bromophenyl azides 2 with alkynes or enolizable aldehydes to furnish 1-(2-bromophenyl)-1,2,3-triazoles $\mathbf{3}$, is more challenging due to the steric hindrance of the ortho-bromo atom. In literature, only a few of these triazole containing precursors have been synthesized so far. ${ }^{[12]}$ In order to generate a diverse library, two methods were employed. The first one is a metal-free enolate-mediated organocatalytic azide-aldehyde [3+2] cycloaddition. ${ }^{[12 c]}$ As demonstrated in Table 1 , different $\mathrm{R}^{1}$-substituents were introduced through cycloaddition of phenyl acetaldehyde with a variety of 2-bromophenyl azides $\mathbf{2}$ in the presence

Table 1. Organocatalytic azide-aldehyde [3+2] cycloaddition: azide substrate scope. ${ }^{[\mathrm{a}]}$

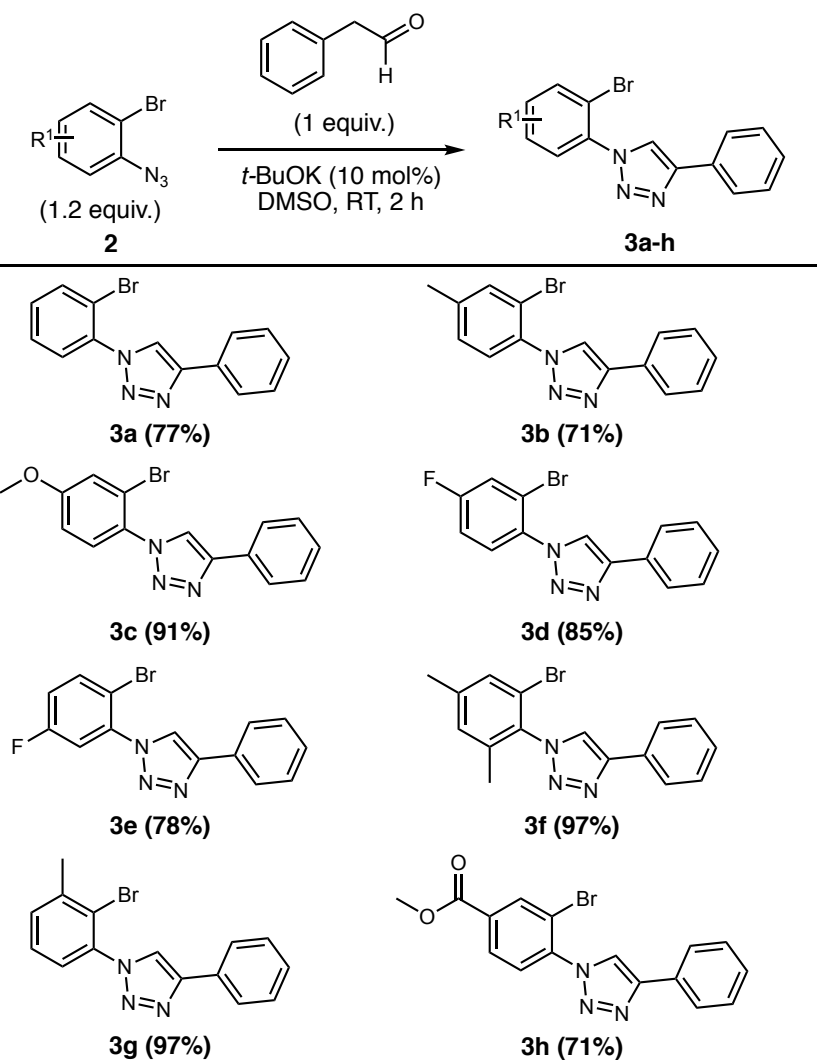

${ }^{[a]}$ Reaction conditions: phenyl acetaldehyde $(0.70 \mathrm{mmol})$, azide 2 (0.84 mmol), $t$-BuOK $(10 \mathrm{~mol} \%)$ in $2 \mathrm{~mL}$ of DMSO at room temperature for 2 hours. Isolated yields. of potassium tert-butoxide in DMSO at room temperature. Both unsubstituted (3a) and substituted (3b-3h) 1- (2-bromophenyl)-1,2,3-triazoles were obtained in good to excellent yields, ranging from $71 \%$ to $97 \%$. The second method - the copper-catalyzed azide-alkyne [3+2] cycloaddition (CuAAC) - could allow variation of the $\mathrm{R}^{2}$-substituent (Table 2). However, upon reacting 2-bromo-4-methylphenyl azide $\mathbf{2 b}$ with 4-ethynyltoluene using the original $\mathrm{CuAAC}$ conditions reported by Sharpless, ${ }^{[13]}$ only $14 \%$ of the desired product $\mathbf{3 i}$ was isolated, while vast amounts of starting material were still present. This observation could potentially be ascribed to the steric hindrance of the bromo substituent. In

Table 2. Copper-catalyzed azide-alkyne [3+2] cycloaddition: alkyne substrate scope. ${ }^{[a]}$

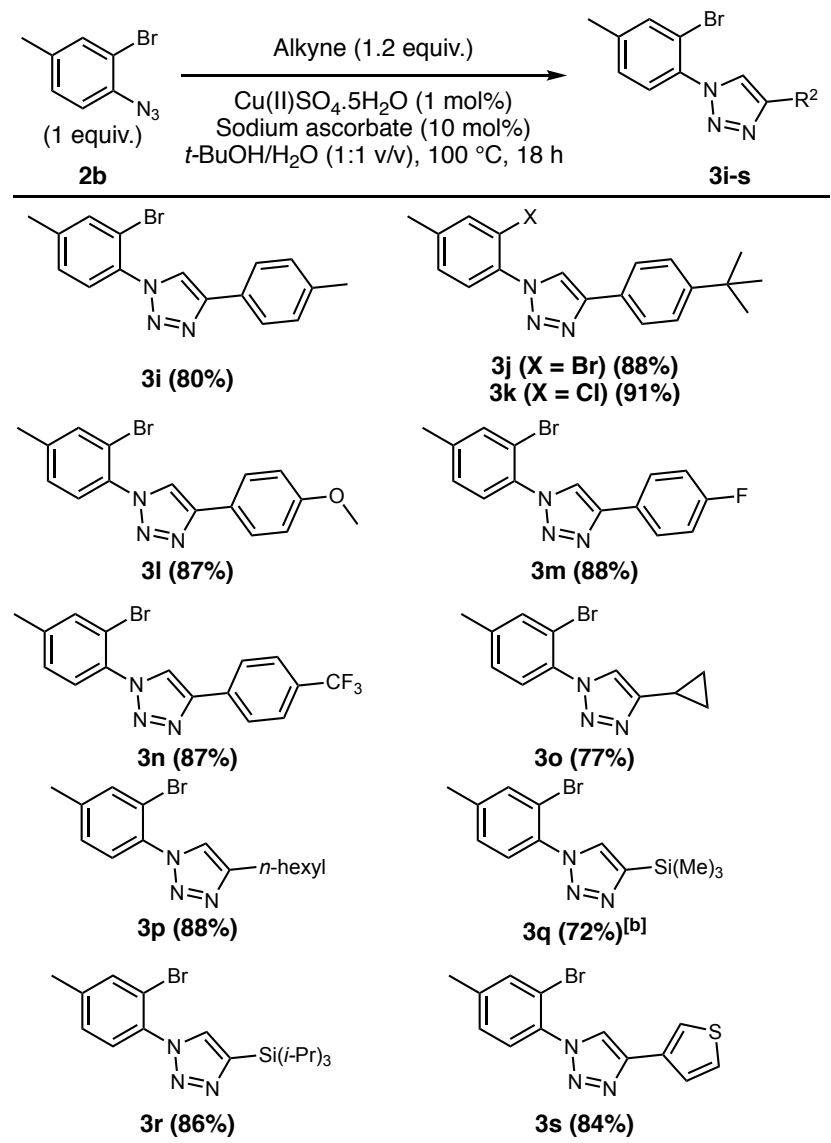

[a] Reaction conditions: 2-bromo-4-methylphenyl azide $\mathbf{2 b}$ $(0.70 \mathrm{mmol})$, alkyne $(0.84 \mathrm{mmol}), \quad \mathrm{Cu}(\mathrm{II}) \mathrm{SO}_{4} .5 \mathrm{H}_{2} \mathrm{O}$ $(1 \mathrm{~mol} \%)$ and sodium ascorbate $(10 \mathrm{~mol} \%)$ in $3 \mathrm{~mL}$ of $t$ - $\mathrm{BuOH} / \mathrm{H}_{2} \mathrm{O}(1: 1 \mathrm{v} / \mathrm{v})$ at $100{ }^{\circ} \mathrm{C}$ for 18 hours. Isolated yields. ${ }^{[\mathrm{b}]} 4$ equivalents of trimethylsilylacetylene were used. 
order to get full conversion, a short optimization study was performed investigating the influence of the catalyst loading, the required amount of reducing agent and the reaction temperature. The details are summarized in the ESI. With the optimized conditions in hand $(1 \mathrm{~mol} \%$ $\mathrm{CuSO}_{4} \cdot 5 \mathrm{H}_{2} \mathrm{O}$ and $10 \mathrm{~mol} \%$ sodium ascorbate in a $t$ - $\mathrm{BuOH} /$ water mixture $(1: 1 \mathrm{v} / \mathrm{v})$ for 18 hours at $\left.100{ }^{\circ} \mathrm{C}\right)$, full conversion of the azide $\mathbf{2 b}$ was achieved, yielding $80 \%$ of 3i. Next, a variety of alkynes were employed to further investigate the scope of the cycloaddition. Aryl alkynes bearing a $t-\mathrm{Bu}(\mathbf{3 j}$ and $\mathbf{3 k})$, an $\mathrm{OMe}(\mathbf{3 I})$, a $\mathrm{F}(\mathbf{3 m})$ and $\mathrm{a} \mathrm{CF}_{3}(\mathbf{3 n})$ group, were suitable for this transformation and gave excellent yields $(87 \% \quad-\quad 91 \%)$ Also cyclopropylacetylene and 1-octyne afforded the desired products in satisfactory yields $(77 \%$ for $\mathbf{3 o}$ and $88 \%$ for $\mathbf{3 p}$ respectively). Subsequently, two silylated acetylenes were tested. Cycloaddition of azide $\mathbf{2 b}$ with 1.2 equivalents of trimethylsilylacetylene furnished $\mathbf{3 q}$ in only $35 \%$ yield. ${ }^{[14]}$ Gratifyingly, performing the same reaction with 4 equivalents of trimethylsilylacetylene afforded $72 \%$ of the desired product. In case of (triisopropylsilyl)acetylene, only 1.2 equivalents were required to obtain $\mathbf{3 r}$ in an excellent yield of $86 \%$. The scope was finalized with the heterocyclic 3-ethynylthiophene, which provided product $3 \mathrm{~s}$ in $84 \%$ yield.
Next, we speculated that the 1-(2-bromophenyl)-1,2,3triazoles could serve as suitable substrates for the palladium-catalyzed intramolecular carbonylative ring closure, generating a new heterocyclic scaffold: the triazolo[1,5- $a$ ]indolone. Although carbon monoxide represents one of the most important $\mathrm{C} 1$ building blocks, safety issues constrain the direct utility of this highly toxic gas. Recently, we have published a study revealing a lowcost and robust carbon monoxide precursor based on formic acid, mesyl chloride and triethylamine. ${ }^{[15]}$ This CO precursor can be used in a two-chamber reactor (COware), ${ }^{[16]}$ in which the desired amount of $\mathrm{CO}$ is generated in one chamber and is consumed in the other (see ESI for details on the reaction setup and CO generation). This approach was previously applied in our group in the carbonylative assembly of helix mimetics. ${ }^{[17]}$

We started our investigation by screening different reaction conditions for the intramolecular carbonylative $\mathrm{C}-\mathrm{H}$ functionalization of substrate $\mathbf{3 j}$. Full conversion was achieved in the presence of $4 \mathrm{~mol} \% \mathrm{Pd}(\mathrm{OAc})_{2}$, $8 \mathrm{~mol}_{\%} \mathrm{PCy}_{3}, 1.5$ equiv. carbon monoxide and 2.0 equiv. potassium carbonate in toluene at $120{ }^{\circ} \mathrm{C}$ for 18 hours, yielding $\mathbf{4 j}$ in $80 \%$ (Table 3). NMR and X-ray crystallography ${ }^{[18]}$ confirmed the structure of this

Table 3. Intramolecular carbonylative C-H functionalization of 1-(2-bromophenyl)-1,2,3-triazoles generating triazolo[1,5-a]indolones. ${ }^{[\mathrm{a}]}$

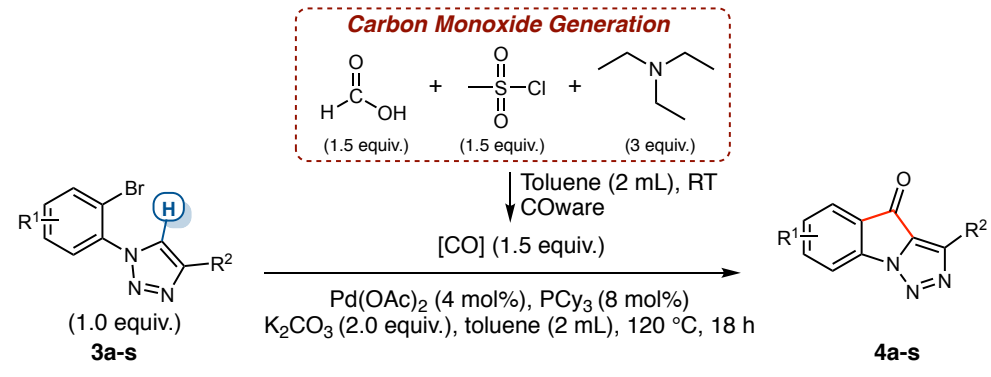

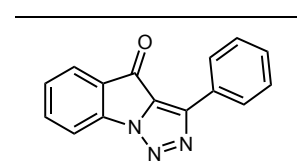

4 a $(92 \%)$<smiles>Cc1cc(C)c2c(c1)C(=O)c1c(-c3ccccc3)nnn1-2</smiles>

$4 f(83 \%)$<smiles>COc1ccc(-c2nnn3c2C(=O)c2cc(C)ccc2-3)cc1</smiles>

41 (93\%)

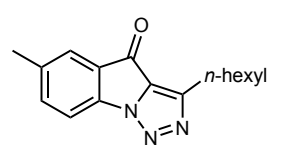

$4 p(92 \%)$<smiles>Cc1ccc2c(c1)C(=O)c1c(-c3ccccc3)nnn1-2</smiles>

$4 b(90 \%)$

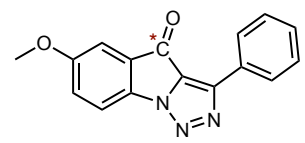

4c $\left({ }^{*} \mathrm{C}={ }^{12} \mathrm{C}\right)(91 \%)$

$4 C^{\star}\left({ }^{*} C={ }^{13} C\right)(92 \%)^{[b]}$<smiles>COC(=O)c1ccc2c(c1)C(=O)c1c(-c3ccccc3)nnn1-2</smiles><smiles>Cc1ccc2c(c1)C(=O)c1c(-c3ccc(F)cc3)nnn1-2</smiles>

$4 \mathrm{~m}(68 \%)$<smiles>Cc1ccc2c(c1)C(=O)c1c(C(C)C)nnn1-2</smiles>

$4 q(0 \%)$ 4h (49\%)<smiles>Cc1ccc2c(c1)C(=O)c1c(-c3ccc(C(F)(F)F)cc3)nnn1-2</smiles>

4n (80\%)<smiles></smiles>

$4 r(34 \%)^{[c]}$<smiles>O=C1c2cc(F)ccc2-n2nnc(-c3ccccc3)c21</smiles>

4d $(76 \%)$<smiles>Cc1ccc(-c2nnn3c2C(=O)c2cc(C)ccc2-3)cc1</smiles><smiles>Cc1ccc2c(c1)C(=O)c1c(C3CC3)nnn1-2</smiles><smiles>Cc1ccc2c(c1)C(=O)c1c(-c3ccsc3)nnn1-2</smiles><smiles>O=C1c2ccc(F)cc2-n2nnc(-c3ccccc3)c21</smiles>

4 e $(64 \%)$

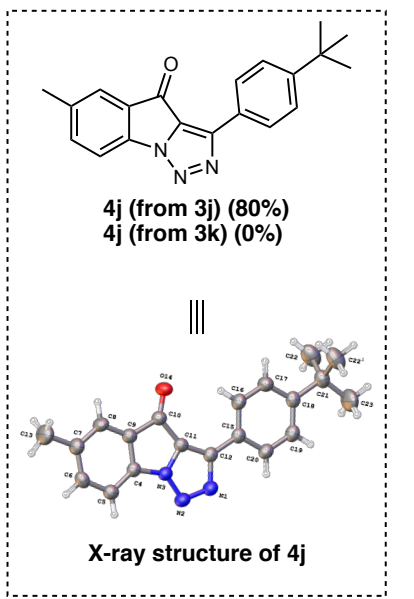

[a] Reaction conditions: 1-(2-bromophenyl)-1,2,3-triazole $3(0.40 \mathrm{mmol}), \mathrm{Pd}(\mathrm{OAc})_{2}(4 \mathrm{~mol} \%), \mathrm{PCy}_{3}\left(8 \mathrm{~mol}^{\circ}\right), \mathrm{K}_{2} \mathrm{CO}_{3}$ $(0.80 \mathrm{mmol})$ and $\mathrm{CO}(0.60 \mathrm{mmol})$ in $2 \mathrm{~mL}$ of dry degassed toluene for $18 \mathrm{~h}$ at $120{ }^{\circ} \mathrm{C}$. See ESI for details on the reaction setup (COware) ${ }^{[16]}$ and $\mathrm{CO}$ generation. Isolated yields. ${ }^{[\mathrm{b}]}{ }^{13} \mathrm{C}-\mathrm{HCOOH}$ was used to generate ${ }^{13} \mathrm{CO}$. ${ }^{[c]} \mathrm{Yield}$ based on ${ }^{1} \mathrm{H}$ NMR. 
compound. Under these conditions, we tried to convert the other synthesized triazoles 3a-s into their corresponding triazolo[1,5- $a]$ indolones. To our delight, unsubstituted and electron rich 1-(2-bromophenyl)-1,2,3-triazoles were excellent substrates as they provided the corresponding triazolo $[1,5-a]$ indolones $(\mathbf{4 a}, \mathbf{4 b}, \mathbf{4 c}$ and $\mathbf{4 f})$ in high yields, ranging from 83 to $92 \%$. Even an ortho-substituted methyl with respect to the bromine yielded the desired compound $\mathbf{4 g}$ in $88 \%$. Electron deficient 1-(2-bromophenyl)-1,2,3triazoles were more challenging as not only the desired triazolo $[1,5-a]$ indolones were formed, but also considerable amounts of the corresponding benzoic acid derivative. ${ }^{[19]}$ Nevertheless, $\mathbf{4 d}, \mathbf{4 e}$ and $\mathbf{4 h}$ were isolated in $76 \%, 64 \%$ and $49 \%$ yield respectively. The nature of the aryl substituent at the 4-position of the triazole could also be varied to furnish the corresponding triazolo[1,5a]indolones in moderate to excellent yields $(83 \%, 93 \%$, $68 \%$ and $80 \%$ for $4 \mathbf{i}, 4 \mathbf{l}, \mathbf{4 m}$ and $4 \mathrm{n}$ respectively). Triazoles with a cyclopropyl and a $n$-hexyl group turned out to be excellent substrates, yielding $\mathbf{4 0}$ in $91 \%$ and $\mathbf{4 p}$ in $92 \%$. Subsequently, silylated triazoles were investigated. Unfortunately, the reaction of triazole $\mathbf{3 q}$ did not provide compound $\mathbf{4 q}$, but a rather complex mixture. This could be ascribed to the instability of the trimethylsilyl group. Performing the same reaction with the more stable triisopropylsilyl group afforded an inseparable mixture of the starting material $\mathbf{3 r}$ and the desired compound $\mathbf{4 r}$. Based on ${ }^{1} \mathrm{H}$ NMR, $34 \%$ of the $4 r$ was formed. Reaction of the thiophene substituted triazole $3 \mathrm{~s}$, yielded substrate $4 \mathrm{~s}$ in $85 \%$. The substrate scope was finalized with ${ }^{13} \mathrm{C}$-carbonyl labeling of $\mathbf{4 c}$, using only near stoichiometric amounts of ${ }^{13} \mathrm{CO}$.

We also wondered whether 1-(2-chlorophenyl)-1,2,3triazoles were suitable substrates in this transformation. Unfortunately, upon reacting substrate $\mathbf{3 k}$ under the same conditions, no conversion towards triazolo[1,5$a$ ] indolone $\mathbf{4} \mathbf{j}$ was observed and the starting material was fully recovered.

In order to enhance the accessibility of the new heterocyclic scaffold, we investigated an alternative pathway using the same reagents (Scheme 3 ). The viability of this approach was demonstrated with one example. First, intermediate $\mathbf{5 j}$ was furnished in $77 \%$ via a palladium-catalyzed carbonylative Sonogashira coupling of 2-bromo-4-methyl aniline $\mathbf{2 b}$ with tertbutylphenylacetylene. ${ }^{[20]}$ Next, a two-step one pot procedure, in which the amine was converted into the azide followed by ruthenium-catalyzed cycloaddition, yielded the triazolo[ $[1,5-a]$ indolone $4 \mathbf{j}$ in $69 \%$. $^{[1,21]}$

In summary, we have presented a new and useful methodology to perform intramolecular ring closure of 1,2,3-triazoles via carbonylative $\mathrm{C}$-H functionalization. This transformation gave direct access to an unprecedented triazolo[1,5-a]indolone. Next, ${ }^{13} \mathrm{C}$-carbonyl labeling was performed to demonstrate the usefulness of late-stage installation of carbon isotopes. Moreover, only nearstoichiometric amounts of $\mathrm{CO}$ were required in the synthesis, attributing to the safety aspects of this method. The study was finalized by enhancing the accessibility towards this new scaffold via an alternative pathway, using the same starting materials. Further applications of this new carbonylation strategy on triazoles are currently in progress in our laboratory.

\section{Experimental Section}

\section{General Procedure for the Intramolecular Carbonylative C-H Functionalization of Triazole (3) towards Triazolo[1,5-a]indolones (4).}

Chamber A of a flame-dried two-chamber reactor (COware $)^{[16]}$ was filled with triazole $3(0.4 \mathrm{mmol}$, 1.0 equiv.), palladium(II) acetate $(3.6 \mathrm{mg}, 0.016 \mathrm{mmol}$, $4 \mathrm{~mol} \%)$, tricyclohexylphosphine $(9.0 \mathrm{mg}, 0.032 \mathrm{mmol}$, $8 \mathrm{~mol} \%)$ and potassium carbonate $(111 \mathrm{mg}, 0.80 \mathrm{mmol}$, 2.0 equiv.). The reactor was brought under nitrogen atmosphere by two consecutive vacuum-nitrogen cycles. Next, chamber B was filled through a septum with $2 \mathrm{~mL}$ of

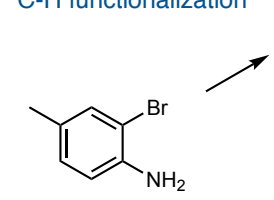<smiles>Cc1ccc(N)c(Br)c1</smiles>

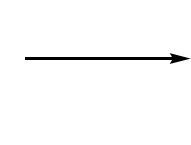

$2 b$
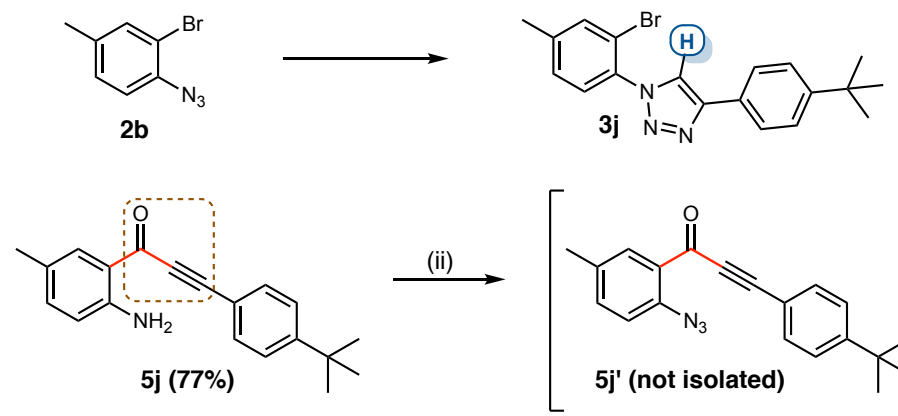
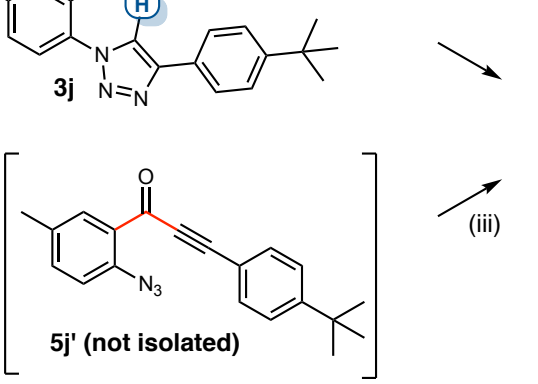

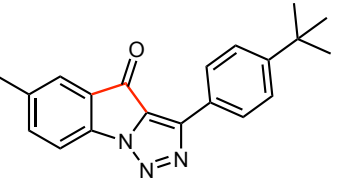

4j (69\%)

$$
\begin{gathered}
\text { Pathway } 2 \\
\text { via carbonylative } \\
\text { Sonogashira coupling }
\end{gathered}
$$

Scheme 3. An alternative pathway towards triazolo[1,5- $a]$ indolones:

(i) carbonylative

(ii) functional group interconversion (iii) and Ru-catalyzed azide-alkyne [3+2] cycloaddition. ${ }^{\text {[a] }}$

${ }^{[\mathrm{a}]}$ Reaction conditions: (i) 2-bromo-4-methylaniline (1.0 mmol), 4-tert-butylphenylacetylene $(2.0 \mathrm{mmol}), \mathrm{PdCl}_{2}(5 \mathrm{~mol} \%)$, Xantphos $(5 \mathrm{~mol} \%), \mathrm{Et}_{3} \mathrm{~N}(3.0 \mathrm{mmol})$ and $\mathrm{CO}(1.50 \mathrm{mmol})$ in $2 \mathrm{~mL}$ of dry degassed dioxane for $18 \mathrm{~h}$ at $100{ }^{\circ} \mathrm{C}$ (ii) compound $\mathbf{5 j}(0.40 \mathrm{mmol}), t$-BuONO $(0.60 \mathrm{mmol}), \mathrm{TMSN}_{3}(0.48 \mathrm{mmol})$ in $5 \mathrm{~mL}$ of acetonitrile for $30 \mathrm{~min}$. at room temperature (iii) intermediate $\mathbf{5} \mathbf{j}^{\prime}(0.40 \mathrm{mmol})$ and $\mathrm{Cp}^{*} \mathrm{RuCl}\left(\mathrm{PPh}_{3}\right)_{2}(2 \mathrm{~mol} \%)$ in $8 \mathrm{~mL}$ of dry degassed dioxane for $18 \mathrm{~h}$ at $60{ }^{\circ} \mathrm{C}$. 
dry degassed toluene, $23 \mu \mathrm{L}$ formic acid $(0.60 \mathrm{mmol}$, 1.5 equiv.) and $47 \mu \mathrm{L}$ mesyl chloride $(0.60 \mathrm{mmol}, 1.5$ equiv.). In chamber A, 2 of dry degassed toluene was added. Finally, $167 \mu \mathrm{L}$ triethylamine $(1.2 \mathrm{mmol}, 3.0$ equiv.) was added by injection through the septum in chamber B and instant gas formation was observed. After 2 minutes, the reactor was immersed in an oil-bath at $120^{\circ} \mathrm{C}$. After 18 hours, the reactor was brought to room temperature and the residual pressure was released carefully by removing one of the caps. As carbon monoxide is a highly toxic gas, the reaction was stirred at room temperature for another 15 minutes to ensure that all carbon monoxide gas was extracted out of the fume hood. Next, the content of chamber A was transferred to a 100 $\mathrm{mL}$ round-bottomed flask. Chamber $\mathrm{A}$ was rinsed five times with $2 \mathrm{~mL}$ of ethyl acetate and these fractions were added to the same flask. After the addition of 1 gram Celite ${ }^{\circledR} 535$, the solvent was removed under reduced pressure. The crude product was purified by solid-phase flash column chromatography on silica gel.

Note: In case triazole $\mathbf{3}$ was a viscous oil (compound $\mathbf{3 0}$ and 3p), it was first dissolved in $1 \mathrm{~mL}$ of dry degassed toluene and was added to chamber $A$ right before the triethylamine was added to chamber B to generate the carbon monoxide.

Note: ${ }^{13} \mathrm{C}$-carbonyl labeling was performed by using $23 \mu \mathrm{L}$ of ${ }^{13} \mathrm{C}-\mathrm{HCOOH}\left(95 \mathrm{wt} \%\right.$ in $\left.\mathrm{H}_{2} \mathrm{O}\right)$.

\section{Acknowledgements}

We are grateful to Karel Duerinckx for the NMR measurements and to prof. dr. Jef Rozenski for HR-MS measurements. CV thanks the FWO (PhD Fellowship of Research Foundation Flanders) for fellowship received. WDB thanks $K U$ Leuven for financial support via project OT/14/067. LVM thanks the Hercules Foundation for supporting the purchase of the diffractometer through project AKUL/09/0035.

\section{References}

[1] For selected reviews on non-carbonylative C-H funtionalization, see: a) L. Ackermann, R. Vicente, A. R. Kapdi, Angew. Chem. Int. Ed. 2009, 48, 9792-9826; b) L. Ackermann, Chem. Rev. 2011, 111, 1315-1345; c) J. Wencel-Delord, T. Droge, F. Liu, F. Glorius, Chem. Soc. Rev. 2011, 40, 4740-4761; d) J. Yamaguchi, A. D. Yamaguchi, K. Itami, Angew. Chem. Int. Ed. 2012, 51, 8960-9009; e) C. B. Bheeter, L. Chen, J.-F. Soule, H. Doucet, Catal. Sci. Technol. 2016, 6, 2005-2049.

[2] a) S. Chuprakov, N. Chernyak, A. S. Dudnik, V. Gevorgyan, Org. Lett. 2007, 9, 2333-2336; b) M. Iwasaki, H. Yorimitsu, K. Oshima, Chem. Asian J. 2007, 2, 1430-1435; c) L. Ackermann, H. K. Potukuchi, D. Landsberg, R. Vicente, Org. Lett. 2008, 10, 30813084; d) L. Ackermann, R. Vicente, R. Born, Adv. Synth. Catal. 2008, 350, 741-748; e) L. Ackermann, A. Althammer, S. Fenner, Angew. Chem. Int. Ed. 2009, 48, 201-204; f) R. Jeyachandran, H. K. Potukuchi, L. Ackermann, Beilstein J. Org. Chem. 2012, 8, 17711777.
[3] For selected reviews on carbonylative C-H funtionalization, see: a) X. F. Wu, H. Neumann, M. Beller, Chem. Rev. 2013, 113, 1-35; b) R. Lang, C. Xia, F. Li, New J. Chem. 2014, 38, 2732-2738; c) S. T. Gadge, P. Gautam, B. M. Bhanage, Chem. Rec. 2016, $16,835-856$.

[4] Z. Lian, S. D. Friis, T. Skrydstrup, Chem. Commun. 2015, 51, 1870-1873.

[5] a) K. Orito, A. Horibata, T. Nakamura, H. Ushito, H. Nagasaki, M. Yuguchi, S. Yamashita, M. Tokuda, J. Am. Chem. Soc. 2004, 126, 14342-14343; b) R. Giri, J.Q. Yu, J. Am. Chem. Soc. 2008, 130, 14082-14083; c) R. Giri, J. K. Lam, J.-Q. Yu, J. Am. Chem. Soc. 2010, 132, 686-693; d) E. J. Yoo, M. Wasa, J.-Q. Yu, J. Am. Chem. Soc. 2010, 132, 17378-17380; e) Z.-H. Guan, M. Chen, Z.-H. Ren, J. Am. Chem. Soc. 2012, 134, 1749017493; f) K. Inamoto, J. Kadokawa, Y. Kondo, Org. Lett. 2013, 15, 3962-3965; g) A. Tlili, J. Schranck, J. Pospech, H. Neumann, M. Beller, Angew. Chem. Int. Ed. 2013, 52, 6293-6297; h) A. McNally, B. Haffemayer, B. S. L. Collins, M. J. Gaunt, Nature 2014, 510, 129-133; i) X. Zhang, S. Dong, X. Niu, Z. Li, X. Fan, G. Zhang, Org. Lett. 2016, 18, 4634-4637.

[6] X.-F. Wu, P. Anbarasan, H. Neumann, M. Beller, Angew. Chem. Int. Ed. 2010, 49, 7316-7319.

[7] a) R. Lang, L. Shi, D. Li, C. Xia, F. Li, Org. Lett. 2012, 14, 4130-4133; b) M.-N. Zhao, L. Ran, M. Chen, Z.-H. Ren, Y.-Y. Wang, Z.-H. Guan, ACS Catal. 2015, 5, 1210-1213.

[8] M. A. Campo, R. C. Larock, Org. Lett. 2000, 2, 36753677.

[9] a) M. A. Campo, R. C. Larock, J. Org. Chem. 2002, 67, 5616-5620; b) B. Lu, J. Wu, N. Yoshikai, J. Am. Chem. Soc. 2014, 136, 11598-11601; c) T. Miura, Y. Funakoshi, Y. Fujimoto, J. Nakahashi, M. Murakami, Org. Lett. 2015, 17, 2454-2457; d) J. Song, F. Wei, W. Sun, K. Li, Y. Tian, C. Liu, Y. Li, L. Xie, Org. Lett. 2015, 17, 2106-2109; e) Q. Han, S. Fu, X. Zhang, S. Lin, Q. Huang, Tetrahedron Lett. 2016, 57, 4165-4169; f) B. W. Yang, S. L. Ho, H.-J. Lim, C. S. Cho, J. Organomet. Chem. 2016, 806, 83-87; g) J. M. Yoo, S. L. Ho, C. S. Cho, Synlett. 2016, 27, 1383-1386; h) J. Zhang, X. Zhang, X. Fan, J. Org. Chem. 2016, 81, 3206-3213.

[10] J. Tjutrins, B. A. Arndtsen, J. Am. Chem. Soc. 2015, $137,12050-12054$.

[11] K. Barral, A. D. Moorhouse, J. E. Moses, Org. Lett. 2007, 9, 1809-1811.

[12] a) X. Meng, X. Xu, T. Gao, B. Chen, Eur. J. Org. Chem. 2010, 2010, 5409-5414; b) D. Wang, N. Li, M. Zhao, W. Shi, C. Ma, B. Chen, Green Chem. 2010, 12, 2120-2123; c) D. B. Ramachary, A. B. Shashank, S. Karthik, Angew. Chem. 2014, 126, 10588-10592; d) H.W. Bai, Z.-J. Cai, S.-Y. Wang, S.-J. Ji, Org. Lett. 2015, 17, 2898-2901; e) B. Choubey, L. Radhakrishna, J. T. Mague, M. S. Balakrishna, Inorg. Chem. 2016, 55, 8514-8526. 
[13] V. V. Rostovtsev, L. G. Green, V. V. Fokin, K. B. Sharpless, Angew. Chem. Int. Ed. 2002, 41, 2596-2599.

[14] The low yield can be ascribed to poor mixing of the reaction components, since most of the silylating reagent is in the gas phase at $100{ }^{\circ} \mathrm{C}$. This was overcome by using an excess of trimethylsilylacetylene.

[15] C. Veryser, S. Van Mileghem, B. Egle, P. Gilles, W. M. De Borggraeve, React. Chem. Eng. 2016, 1, 142146.

[16] a) S. D. Friis, R. H. Taaning, A. T. Lindhardt, T. Skrydstrup, J. Am. Chem. Soc. 2011, 133, 1811418117 ; b) P. Hermange, A. T. Lindhardt, R. H. Taaning, K. Bjerglund, D. Lupp, T. Skrydstrup, J. Am. Chem. Soc. 2011, 133, 6061-6071.

[17] S. Van Mileghem, B. Egle, P. Gilles, C. Veryser, L. Van Meervelt, W. M. De Borggraeve, Org. Biomol. Chem. 2017, 15, 373-378.
[18] CCDC-1522953 contains the supplementary crystallographic data for this paper. These data can be obtained free of charge from The Cambridge Crystallographic Data Centre via http://www.ccdc.cam.ac.uk/data\%5Frequest/cif.

[19] A similar observation is reported in the C-H activation dependent palladium-catalyzed carbonylative coupling of (hetero)aryl bromides and polyfluoroarenes. See ref. 4.

[20] K. T. Neumann, S. R. Laursen, A. T. Lindhardt, B. Bang-Andersen, T. Skrydstrup, Org. Lett. 2014, 16, 2216-2219.

[21] B. C. Boren, S. Narayan, L. K. Rasmussen, L. Zhang, H. Zhao, Z. Lin, G. Jia, V. V. Fokin, J. Am. Chem. Soc. 2008, 130, 8923-8930. 
Intramolecular Carbonylative $\mathrm{C}-\mathrm{H}$

Functionalization of 1,2,3-Triazoles for the

Synthesis of Triazolo[ $[1,5-a]$ indolones

Adv. Synth. Catal. Year, Volume, Page - Page

Cedrick Veryser, Gert Steurs, Luc Van Meervelt

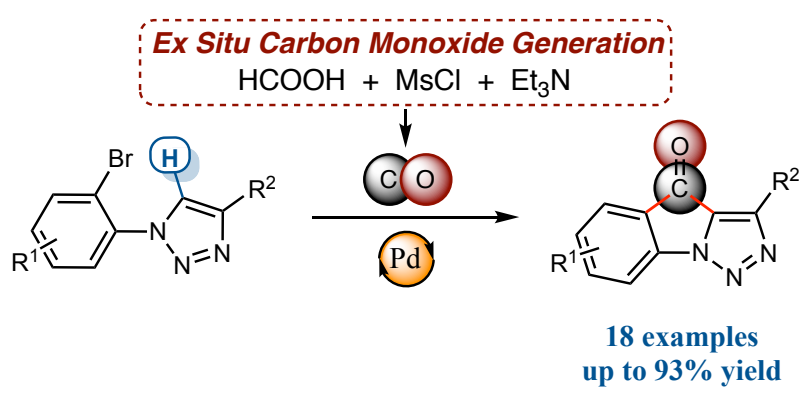
and Wim M. De Borggraeve* 